\title{
Phytochemical Composition, Proximate Analysis and Antimicrobial Screening of the Methanolic Extract of Diospyros mespiliformis Hochst ex a. Dc (Ebenaceae)
}

\author{
Abdullahi Aliyu Ebbo ${ }^{1,2,}$, Dahiru Sani ${ }^{2}$, Mohammed Musa Suleiman², Abubakar Ahmed ${ }^{3}$, Adamu Zoaka Hassan ${ }^{4}$
}

\section{Abdullahi Aliyu Ebbo ${ }^{1,2, *}$, Dahiru Sani², Mohammed Musa Sulei- man $^{2}$, Abubakar Ahmed ${ }^{3}$, Adamu Zoaka Hassan ${ }^{4}$}

'Department of Veterinary Pharmacology and Toxicology, Faculty of Veterinary Medicine, Usmanu Danfodiyo University Sokoto, NIGERIA.

${ }^{2}$ Department of Veterinary Pharmacology and Toxicology, Faculty of Veterinary Medicine, Ahmadu Bello University Zaria, NIGERIA.

${ }^{3}$ Department of Pharmacognosy, Faculty of Pharmaceutical Sciences, Ahmadu Bello University Zaria, NIGERIA. ${ }^{4}$ Department of Veterinary Surgery, Faculty of Veterinary Medicine, Ahmadu Bello University Zaria, NIGERIA.

Correspondence

\section{Dr. Abdullahi Aliyu Ebbo}

Department of Veterinary Pharmacology and Toxicology, Faculty of Veterinary Medicine, Usmanu Danfodiyo University Sokoto, NIGERIA.

Phone no : +2348036153080

E-mail: aaliyuebbo@yahoo.co.uk

History

- Submission Date: 08-11-2018

- Review completed: 17-12-2018;

- Accepted Date: 03-01-2019.

DOI : 10.5530/pj.2019.11.55

Article Available online

http://www.phcogj.com/v11/i2

Copyright

(C) 2019 Phcog.Net. This is an openaccess article distributed under the terms of the Creative Commons Attribution 4.0 International license.

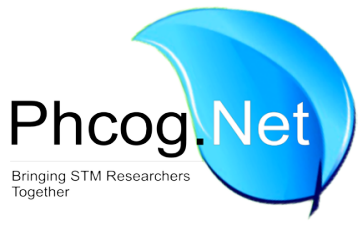

\begin{abstract}
Aim: Diospyros mespiliformis is one plant used by the natives for the treatment of certain diseases including wounds. In this present study, preliminary screening of the methanolic leaf extract of $D$. mespiliformis was carried out for its phytochemical and proximate constituents in addition to investigating its antimicrobial activity against four bacteria species. Methodology: Preliminary phytochemical and proximate analysis were carried out using standard methods. The antimicrobial activity was conducted using the whole in-plate and broth serial micro dilution assays on two Gram positive bacteria (Staphylococcus aureus, Salmonella typhymurium) and two Gram negative bacteria (Pseudomonas aeruginosa and Escherichia coll). Results: The phytochemical screening showed the presence of alkaloids, tannins, saponins, glycosides, anthraquinones, flavonoids and volatile oil. Similarly, preliminary proximate analysis of the root, bark and leaf extracts of $D$. mespiliformis exerts revealed the presence of carbohydrate, crude protein, moisture, lipid and nitrogen, ash and fibre. The extract demonstrated greater inhibitory activity on P. aeruginosa, S. aureus and $E$. coli $(\mathrm{MIC}=156.25 \mu \mathrm{g} / \mathrm{ml})$ than on S. typhymurium $(\mathrm{MIC}=312.5 \mu \mathrm{g} / \mathrm{ml}$ ). Conclusion: These findings revealed that the crude methanolic extract of $D$. mespiliformis and its fractions demonstrated broad spectrum antimicrobial activity in a dose dependent manner.

Key words: Phytochemical, Proximate, Antimicrobial, Diospyros mespiliformis, Extract.
\end{abstract}

\section{INTRODUCTION}

A wide range of antibiotics are being used at present to treat certain infections but they have been proven to have adverse effects like hypersensitivity (e.g penicillin), ototoxicity (e.g. aminoglycosides). Apart from these discouraging side effects of many antibiotics, pathogens have also been shown to develop resistance to the antibiotics targeted against them..$^{1-2}$ Example is the Methicillin-resistant Staphylococcus aureus (MRSA).

In view of this tendency of bacterial resistance to drugs, the scientific search for new antibiotics from natural plants remains a serious burden worldwide. ${ }^{3}$ The World Health Organization (WHO) in recognition of the immense value of herbal medicine to primary health care delivery has advocated for proper identification, sustainable exploitation, scientific development and appropriate utilization of herbal medicines which provide safe and effective remedies in Medicare. ${ }^{4}$ Even in the developed countries, the popularity of crude herbal products is on the increase. ${ }^{5}$

Diospyros mespiliformis belongs to the family of Ebenaceae and is commonly called Jackal berry or African ebony. In Nigeria, the plant is popularly known in Hausa as Kanya and in Yoruba as Igidudu. It is found in savanna and northern low-land forest and is an ever green tree of $12-15 \mathrm{~m}$ height but sometimes reaching $20 \mathrm{~m}$ or more in the rain forest. The leaves are simple and alternate in arrangement and dark green in coloration. ${ }^{6}$ Several studies have reported on the compositional properties of various plants abound in scientific literature. ${ }^{7}$ Ethno botanical application of different parts of the plant includes remedy against malaria, pneumonia, syphilis, leprosy, dermatomycoses, diarrhea, helminths and to facilitate delivery. ${ }^{8-10}$ A decoction of the leaves is a common remedy against fever, whooping cough and to heal wounds. ${ }^{11-13}$ Studies on the biological activity of $D$. mespiliformis have also been reported..$^{6,12,14,15}$ Despite wide use of this plants to treat various ailments, limited attempts have been made to scientifically evaluate its potentials for use in modern medicine. Hence, this present study aim to determine the phytochemical constituent, proximate composition and antimicrobial property of the crude methanol extract of D. mespiliformis and its fraction. 


\section{MATERIAL AND METHODS}

\section{Plant collection and identification}

Fresh leaves, bark and root of D. mespiliformis $(800 \mathrm{~g})$ each were collected from Basawa area, Zaria, Nigeria. Samples of the leaves, flowers and fruits of the plant were taken to the Herbarium, Department of Biological Sciences, Ahmadu Bello University, Zaria for identification by Namadi Sunusi. A voucher specimen number, 938, was issued. The collected plant parts were air - dried in the laboratory under a stream of fast moving air and pulverized using mortar and pestle. The powdered plant parts were put in sealed plastic containers, labeled and kept at $4^{\circ} \mathrm{C}$ until required.

\section{Preparation of extract}

Five hundred grams $(500 \mathrm{~g})$ of the powdered form of each plant part was mixed with two litres of methanol and allowed to stand for $24 \mathrm{~h}$. Thereafter, the liquid extract was decanted and the process was repeated twice. The decanted liquid extracts of each plant part were pooled together and filtered using Whatman filter paper size 1. The liquid extracts were allowed to evaporate at room temperature under a fast stream of moving air. ${ }^{16}$ The percentage yield for each plant part extract was then calculated using the formula as described by. ${ }^{16}$

$$
\% \text { Yield }=\frac{\text { Weight of extract }}{\text { Weight of pulverized material }} \times 100
$$

\section{Partitioning of the methanol extract of $D$. mespiliformis}

The methanol extract of each plant part of D. mespiliformis was partioned as earlier described. ${ }^{15-16}$ Ten grams $(10 \mathrm{~g})$ of the methanol extract was dissolved in $200 \mathrm{~mL}$ of distilled water in a separatory funnel and an equal volume of n-hexane was added and allowed to stand for $30 \mathrm{~min}$. The individual mixtures were separated into nhexane and aqueous portions. The n-hexane portion was concentrated to dryness under a stream of fast moving air to obtain $n$-hexane extract. The water portion of each extract was transferred into the separatory funnel and mixed with equal volume of ethyl acetate in each case and left for $30 \mathrm{~min}$, to have a clear separation after shaking. The ethyl acetate portion was collected and concentrated as described for $\mathrm{n}$-hexane. In a similar fashion, the water portion was mixed with equal volume of butanol in a separatory funnel and left to stand for $30 \mathrm{~min}$. The butanol portion was collected and concentrated under a fast stream of moving air. Similarly, the water portion was concentrated to dryness. The individual fractions or extracts of each plant parts were collected, labeled and stored for further used.

\section{Qualitative phytochemical screening of the plant extracts}

Five gram of each extract was dissolved in $50 \mathrm{ml}$ of distilled water and used for phytochemical tests. Flavonoids, tannins and steroids were determined according to the standard methods. ${ }^{17}$ Saponins, cardiac glycosides and anthraquinones were determined according to the method by. ${ }^{18}$ Alkaloid by ${ }^{19}$ while volatile oil was determined as described by. ${ }^{20}$

\section{Proximate analysis analysis of the plant parts of D. mespiliformis}

The plant samples were air dried and ground into powder. Ten grams were exhaustively processed for various parameters according to the methods described by the association of physical analytical chemists. ${ }^{21}$ By the use of weight difference, ash and moisture were obtained. The fibre content was estimated from the loss in weight of crucible and its content on drying. Carbohydrate was determined by subtracting the sum of the percentages of moisture, crude protein, ash and fats from 100. The determination of nitrogen value (precursor of protein of a substance) was by Microkjeldahi method which involves digestion, distillation and finally titration of the sample. ${ }^{22}$ The nitrogen value was then converted to protein by multiplying it by a factor of 6.25 . Crude lipids content was determined by the use of soxhlet type of direct solvent extraction method using petroleum ether boiling at $50^{\circ} \mathrm{C}$. The nitrogen free extracts was calculated indirectly by difference as the sum of crude protein, fibre, fats and ash subtracted from one hundred. All the results of proximate analysis were expressed in percentages.

\section{Microorganisms}

All the bacteria strains used in this study mainly Staphylococcus aureus, Salmonella typhymurium, Pseudomonas aeruginosa and Escherichia coli were obtained from Phytomedicine Laboratory, University of Pretoria, South Africa and maintained in nutrient broth media at $37^{\circ} \mathrm{C}$.

\section{Antibacterial screening}

The antibacterial activity was carried out by utilizing the hole-in-plate bioassay procedure. ${ }^{23}$ Pure cultures of Staphylococcus aureus, Salmonella typhymurium, E. coli and P. aerugenosa, were inoculated into MullerHinton nutrient broth (Oxoid, England) and incubated at $37^{\circ} \mathrm{C}$ for $24 \mathrm{~h}$. The bacteria cultures was further diluted with sterile nutrient broth to a density of $9 \times 10^{8} \mathrm{cfu} / \mathrm{mL}$ equivalent to McFarland standard and the suspensions were used to streak for confluent growth on the surface of Muller-Hinton agar plates with sterile swab. Thereafter, using a sterile cork-borer (6 mm diameter), 4 holes (wells) were dug into the solidified agar in petri-dishes containing the bacterial culture. Each of the crude leaf methanol fractions and procaine penicillin (used as reference standard drug) were constituted to obtain the concentrations of 6,12 , 18 and $24 \mathrm{mg} / \mathrm{mL}$ respectively and poured into the wells. All the cultured plates were allowed to stand for few $\mathrm{min}$ at room temperature prior to incubation at $37^{\circ} \mathrm{C}$ for $24 \mathrm{~h}$. The zones of inhibition of the bacteria growth produced by each test agent were measured as an indication of antibacterial activity. All the assays were done in triplicate and the averages were recorded.

\section{Minimum inhibitory concentration (MIC)}

The minimum inhibitory concentration (MIC) of each extract was determined using the broth serial microdilution assay method in a 96-well microtitre plate using the method described by. ${ }^{24}$ Bacterial cultures (S. aureus, $2.6 \times 10^{12} \mathrm{cfu} / \mathrm{mL}$; Salmonella typhymurium, $1.5 \times 10^{10} \mathrm{cfu} / \mathrm{ml}$; $P$. aeruginosa, $5.2 \times 10^{13} \mathrm{cfu} / \mathrm{ml}$; Escherichia coli, $3.0 \times 10^{11} \mathrm{cfu} / \mathrm{mL}$ were sub-cultured from Mueller Hinton (MH) agar plates. A $1 \%$ inoculum of the organism was individually transferred to $\mathrm{MH}$ broth and incubated over night at $37^{\circ} \mathrm{C}$. Microtitre plates were prepared by addition of $100 \mu \mathrm{L}$ of distilled sterilized water to each well. A stock concentrations of $2500 \mu \mathrm{g} / \mathrm{mL}$ was prepared for each for the extract and the standard reference drug (gentamicin). Thereafter, a $100 \mu \mathrm{L}$ aliquot of each of the extracts were taken and used for two-fold serial dilution into the $\mathrm{MH}$ broth (containing $100 \mu \mathrm{L}$ of the bacteria cultures), to obtain 2500,1250 , $625,312.5,156.25,78.125,39.06,19.53 \mu \mathrm{g} / \mathrm{mL}$ respectively. Acetone was used as negative control. This $50 \%$ inoculum ensured there was no lag phase in the growth of the microorganism. ${ }^{25}$ The plates were airtight sealed and incubated at $37^{\circ} \mathrm{C}$ under $100 \%$ relative humidity conditions overnight. Thereafter, $40 \mu \mathrm{L}$ of $0.2 \mathrm{mg} / \mathrm{mL}$ 2-(4-iodophenyl)3-(4-nitrophenyl)-5-phenyl-2H-tetrazolium chloride (INT) solution was added to all inoculated wells to determine growth inhibition of the microbes. The bacterial growth inhibitions were then observed after the addition of INT. ${ }^{26}$

\section{Statistical analysis}

Data obtained were expressed in mean \pm standard error of mean (SEM) and subjected to one-way ANOVA to assess significant difference between groups followed by Tukey post-hoc test to examine significant difference $(P \leq 0.05)$. 
Table 1: Percentage yields of extracts of Diospyros mespiliformis after extraction and partitioning.

\begin{tabular}{cccc}
\hline Plant parts & Extracts & Yield $(\mathrm{g})$ & Percentage yield (\%) \\
\hline Root & Hexane & 1.49 & 14.9 \\
& Ethyl acetate & 4.48 & 44.8 \\
& Saturated butanol; & 2.90 & 29.0 \\
& Water & 1.10 & 11.0 \\
& Crude methanol & 25.8 & 5.16 \\
Bark & Hexane & 1.10 & 11.0 \\
& Ethyl acetate & 3.39 & 33.9 \\
& Saturated butanol; & 4.28 & 42.8 \\
& Water & 1.20 & 12.0 \\
& Crude methanol & 33.8 & 6.76 \\
& Hexane & 3.29 & 42.9 \\
& Ethyl acetate & 2.40 & 24.0 \\
& Saturated butanol; & 3.78 & 37.8 \\
& & &
\end{tabular}

\section{RESULTS}

\section{Extract Yeild}

The yield of the crude methanol extracts and those of the partitioned portions of $D$. mespiliformis using solvents of varying polarities are presented on Table 1. Crude methanol extract yield of the leaf, root and the bark of D. mespiliformis were $141.2 \mathrm{~g}, 25.8 \mathrm{~g}$ and $33.8 \mathrm{~g}$, representing $28.24 \%, 5.16 \%$ and $6.76 \%$, respectively. In the case of the fractions of the crude methanol root extract, the ethyl acetate portion gave the highest yield of $4.48 \mathrm{~g}(44.8 \%)$ while hexane fraction was the least with the yield of $1.49 \mathrm{~g} \mathrm{(14.9 \% ).} \mathrm{The} \mathrm{root} \mathrm{butanol} \mathrm{fraction} \mathrm{gave} \mathrm{a} \mathrm{yield} \mathrm{of} 2 \mathrm{~g}(29.0 \%)$. The hexane fraction of the bark methanol extract gave the yield of $1.1 \mathrm{~g}$ (11\%), while the ethyl acetate fraction gave the yield of $3.39 \mathrm{~g}$ (33.9\%) and butanol fraction gave the yield of $3.29 \mathrm{~g}(38.9 \%)$. The highest yield of the fractions of the leaf crude methanol extract of $D$. mespiliformis was from butanol fraction that gave the yield of $3.78 \mathrm{~g}$ (37.8\%). Ethyl acetate fraction of the leaf gave the yield of $2.4 \mathrm{~g}(24 \%)$. The yield of the leaf crude methanol fractions was from water fraction that gave $0.51 \mathrm{~g}$ (5.1\%).

\section{Qualitative presence of phytochemical constituents of D. mespiliformis Extract}

The metabolites detected in the extracts of different parts (leaf, bark and root) of $D$. mespiliformis are shown in Table 2. The extracts of the leaf, bark and root of D. mespiliformis contain alkaloids, cardiac glycosides, saponins, steroids and tannins. Similarly, all the fractions, except butanol fractions of the bark and leaf of D. mespiliformis contain volatile oils. All the fractions of the bark and root contain anthraquinones. The crude methanol extracts of all the plant parts (leaf, root and bark), the butanol fractions of the bark and the root contain saponin glycosides. In addition, the crude methanol extract, ethyl acetate and butanol fractions of the leaf of the plant contain flavonoids.

\section{Proximate Analysis of the Plant Parts of Diospyros mespiliformis}

The result of the proximate analyses of the root, leaf and bark of D. mespiliformis is shown in Table 3. The root had the highest percentage of carbohydrate $(73.99 \pm 0.17 \%)$, followed by the leaf $(55.03 \pm 0.01 \%)$ and then the bark $(50.96 \pm 25 \%)$ The leaf had the highest percentage of crude protein $(11.49 \pm 0.10 \%)$, followed by the bark $(5.51 \pm 0.10 \%)$ and the root $(3.9 \pm 0.10 \%)$. The leaf had the highest percentage of moisture $(14.83 \pm 0.04 \%)$, lipid $(3.0 \pm 0.01 \%)$ and nitrogen $(1.83 \pm 0.01 \%)$. This

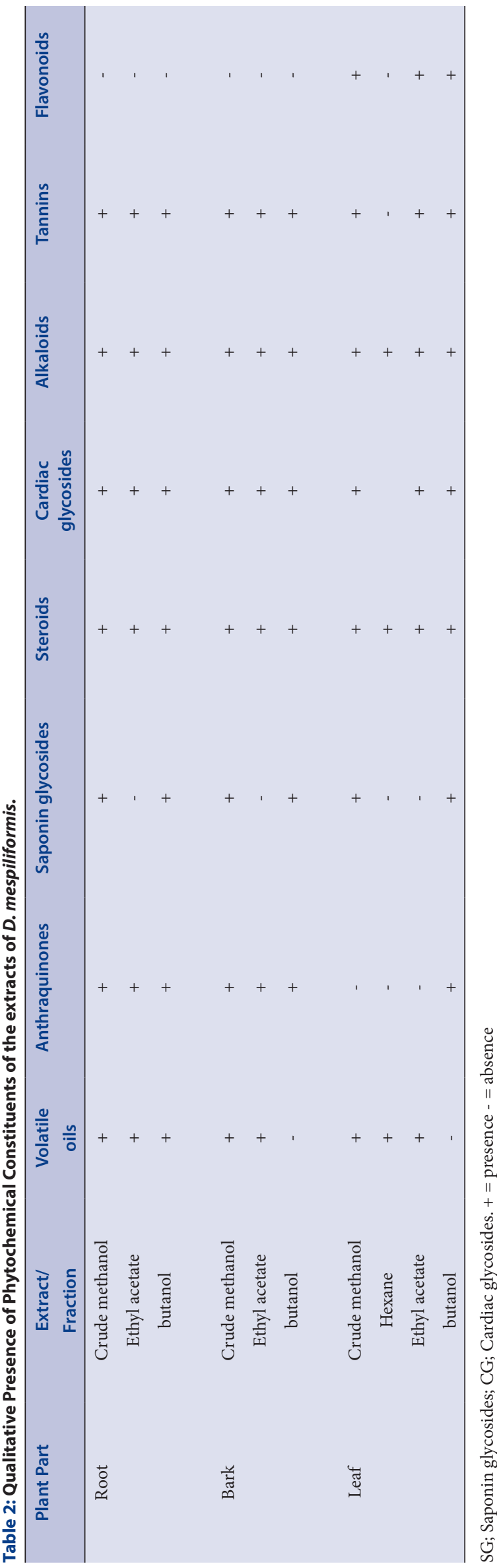

Pharmacognosy Journal, Vol 11, Issue 2, Mar-Apr, 2019 
Table 3: Proximate Analysis of the Root, Leaf and Bark of D. mespiliformis.

\begin{tabular}{cccc}
\hline Parameters (\%) & Root & Bark & Leaf \\
\hline Moisture & $3.33 \pm 0.33$ & $11.33 \pm 0.60$ & $14.83 \pm 0.44$ \\
Ash & $13.16 \pm 0.33$ & $22.66 \pm 0.33$ & $11.16 \pm 0.44$ \\
Lipid & $1.16 \pm 0.16$ & $1.83 \pm 0.16$ & $3.00 \pm 0.01$ \\
Fibre & $3.83 \pm 0.16$ & $6.83 \pm 0.33$ & $2.66 \pm 0.16$ \\
Crude Protein & $3.90 \pm 0.10$ & $5.51 \pm 0.10$ & $11.49 \pm 0.10$ \\
Nitrogen & $0.63 \pm 0.01$ & $0.88 \pm 0.01$ & $1.83 \pm 0.01$ \\
Carbohydrate & $73.99 \pm 0.17$ & $50.96 \pm 0.25$ & $55.03 \pm 0.01$ \\
\hline
\end{tabular}

Results are presented as mean \pm SEM.

Table 4: Effects of fractions of different parts of Diospyros mespiliformis against different bacterial species.

\begin{tabular}{|c|c|c|c|c|c|}
\hline \multicolumn{6}{|c|}{ Zone of Inhibition ( $\mathrm{mm}$ ) } \\
\hline 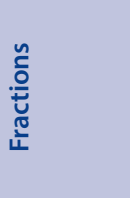 & 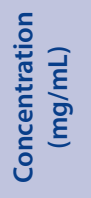 & ثَ & 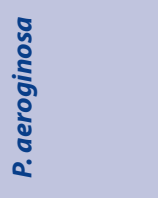 & 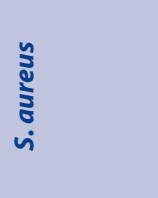 & 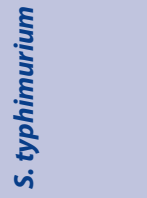 \\
\hline \multirow{4}{*}{$\begin{array}{l}\text { Leaf ethyl } \\
\text { acetate }\end{array}$} & 6 & $10.00 \pm 1.53$ & $4.33 \pm 0.33$ & $10.33 \pm 0.33$ & $9.00 \pm 0.58$ \\
\hline & 12 & $11.33 \pm 3.53$ & $7.33 \pm 0.88$ & $13.33 \pm 0.67$ & $11.00 \pm 0.58$ \\
\hline & 18 & $14.00 \pm 3.46$ & $9.00 \pm 1.00$ & $14.00 \pm 1.15$ & $11.67 \pm 1.20$ \\
\hline & 24 & $15.00 \pm 3.46$ & $10.00 \pm 1.00$ & $15.00 \pm 1.15$ & $12.67 \pm 1.20$ \\
\hline \multirow{4}{*}{$\begin{array}{c}\text { Root } \\
\text { butanol }\end{array}$} & 6 & $3.33 \pm 0.67$ & $6.33 \pm 0.33$ & $4.67 \pm 0.33$ & $7.00 \pm 0.58$ \\
\hline & 12 & $7.00 \pm 0.58$ & $7.00 \pm 0.58$ & $5.67 \pm 0.33$ & $8.33 \pm 0.33$ \\
\hline & 18 & $8.00 \pm 0.58$ & $9.00 \pm 0.58$ & $8.33 \pm 0.33$ & $9.00 \pm 0.58$ \\
\hline & 24 & $9.33 \pm 0.33$ & $9.00 \pm 1.15$ & $10.33 \pm 0.33$ & $9.67 \pm 0.33$ \\
\hline \multirow{4}{*}{$\begin{array}{c}\text { Leaf } \\
\text { hexane }\end{array}$} & 6 & $5.67 \pm 0.33$ & $00 \pm 00$ & $5.67 \pm 0.67$ & $6.67 \pm 0.33$ \\
\hline & 12 & $9.67 \pm 0.88$ & $6.33 \pm 0.58$ & $8.00 \pm 0.58$ & $8.33 \pm 0.33$ \\
\hline & 18 & $11.33 \pm 0.67$ & $7.00 \pm 0.58$ & $9.67 \pm 0.33$ & $11.67 \pm 1.67$ \\
\hline & 24 & $12.33 \pm 0.67$ & $9.00 \pm 0.58$ & $11.00 \pm 0.58$ & $12.67 \pm 0.67$ \\
\hline \multirow{4}{*}{$\begin{array}{l}\text { Bark ethyl } \\
\text { acetate }\end{array}$} & 6 & $5.67 \pm 0.33$ & $9.00 \pm 0.58$ & $7.00 \pm 0.58$ & $5.67 \pm 0.33$ \\
\hline & 12 & $7.67 \pm 0.33$ & $10.00 \pm 0.58$ & $8.00 \pm 0.58$ & $7.00 \pm 0.58$ \\
\hline & 18 & $9.33 \pm 0.33$ & $15.33 \pm 1.20$ & $9.00 \pm 1.53$ & $10.00 \pm 0.58$ \\
\hline & 24 & $12.00 \pm 0.58$ & $15.67 \pm 1.45$ & $10.33 \pm 1.86$ & $13.67 \pm 1.45$ \\
\hline \multirow[t]{4}{*}{ Penicillin } & 6 & $9.33 \pm 1.45$ & $8.00 \pm 1.00$ & $10.00 \pm 2.65$ & $13.67 \pm 0.88$ \\
\hline & 12 & $11.00 \pm 0.58$ & $12.33 \pm 1.45$ & $10.00 \pm 0.58$ & $14.00 \pm 1.15$ \\
\hline & 18 & $14.67 \pm 1.45$ & $12.33 \pm 1.45$ & $10.67 \pm 0.88$ & $18.00 \pm 1.15$ \\
\hline & 24 & $18.00 \pm 4.04$ & $15.33 \pm 3.71$ & $11.33 \pm 0.88$ & $21.00 \pm 2.52$ \\
\hline
\end{tabular}

Mean in the same column with different superscripts letter are significantly different $(\mathrm{P}<0.05)$.

was followed by bark which had moisture $(11.33 \pm 0.60 \%)$, lipid $(1.83 \pm$ $0.16 \%)$ and nitrogen $(0.88 \pm 0.01 \%)$. The root had the lowest percentage of moisture $(3.33 \pm 0.33 \%)$, lipid $(1.16 \pm 0.16 \%)$ and nitrogen $(0.63 \pm$ $0.01 \%)$. The bark had the highest percentage of both ash $(22.66 \pm 0.33 \%)$ and fibre $(6.83 \pm 0.33 \%)$. This was followed by the root which had $13.16 \pm$
$0.33 \%$ of ash and $3.83 \pm 0.16 \%$ of fibre. The leaf had the lowest percentage of ash $(11.16 \pm 0.44 \%)$ and fibre $(2.66 \pm 0.16 \%)$.

\section{Effect of D. mespiliformes fractions on the Growth and Minimum Inhibitory Concentration (MIC) of some Bacteria}

The antibacterial effects of some fractions of $D$. mespiliformis as shown by zone of inhibition in millimeters $(\mathrm{mm})$ on different bacterial organisms are presented in Table 4. The antibacterial effects of all the fractions against Escherichia coli (E. coli) were concentration-dependent. The ethyl acetate fraction of the leaf of $D$. mespiliformis had the highest zone of exhibition $(10 \pm 1.53 \mathrm{~mm})$ against $E$. coli at $6 \mathrm{mg} / \mathrm{mL}$. The butanol fraction of the root of $D$. mespiliformis had the lowest zone of inhibition against $E$. coli $(3.33 \pm 0.67 \mathrm{~mm})$ at $6 \mathrm{mg} / \mathrm{mL}$. The hexane fraction of the leaf (HEL) had no effect against $P$. aeruginosa at $6 \mathrm{mg} / \mathrm{mL}$. However, the extract produced a zone of inhibition of $9.00 \pm 0.58 \mathrm{~mm}$ against the bacterium at $24 \mathrm{mg} / \mathrm{mL}$. The ethyl acetate fraction of bark produced zone of inhibition of $15.67 \pm 1.45 \mathrm{~mm}$ against $P$. aeruginosa at $24 \mathrm{mg} / \mathrm{mL}$. The antibacterial effect shown by the ethyl acetate fraction of bark at $24 \mathrm{mg} / \mathrm{mL}(15.67 \pm 1.45 \mathrm{~mm})$ is comparable to that produced by penicillin $(15.33 \pm 3.71 \mathrm{~mm})$ which is a standard antibiotic. The leaf ethyl acetate fraction, even at its lower concentration of $12 \mathrm{mg} / \mathrm{mL}$, gave higher zone of inhibition $(10.33 \pm 0.33 \mathrm{~mm})$ against Staphlococus aureus than the highest concentration of all other fractions, including penicillin which recorded $11.33 \pm 0.88 \mathrm{~mm}$ at its highest concentration of $24 \mathrm{mg} / \mathrm{mL}$. Although leaf ethyl acetate (LEF) fraction, gave the best zone of inhibition of $12.67 \pm 1.20 \mathrm{~mm}$ at its highest concentration of $24 \mathrm{mg} / \mathrm{mL}$ against S. typhimurium, among all other extracts, penicillin gave an outstanding zone of inhibition of $13.67 \pm 0.88 \mathrm{~mm}$ at its lowest concentration of $6 \mathrm{mg} / \mathrm{mL}$.

The minimum inhibitory concentration (MIC) of the extracts of Diospyros mespiliformis on some bacteria

The MIC of the crude methanol extracts of the leaf, root and bark of Diospyros mespiliformis is shown on Table 5. The leaf crude methanol extract had the lowest MIC on all the test bacteria $(625 \mu \mathrm{g} / \mathrm{mL})$. The root crude methanol extract was effective only against Psuedomonas aeruginosa with MIC of $625 \mu \mathrm{g} / \mathrm{mL}$ while the bark methanol extract was effective against P. aerugenosa and Staphylococcus aureus, with MIC of $625 \mu \mathrm{g} / \mathrm{mL}$. However, none of the extracts (leaf, root or bark) activities was comparable with gentamicin $(19.53 \mu \mathrm{g} / \mathrm{mL})$.

Table 5: Minimum Inhibitory Concentration of Crude Methanol Extracts of Leaf, Root and Bark of Diospyromis mespiliformis.

\begin{tabular}{ccccc}
\hline $\begin{array}{c}\text { Methanol } \\
\text { Extract }(\mu \mathrm{g} / \mathrm{mL})\end{array}$ & $\begin{array}{c}\text { P. } \\
\text { aeroginosa }\end{array}$ & S. aureus & E. coli & S. typhimurium \\
\hline Bark & 625 & 625 & $>2500$ & $>2500$ \\
Leaf & 625 & 625 & 625 & 625 \\
Root & 625 & $>2500$ & $>2500$ & $>2500$ \\
Gentamicin & 19.53 & 19.53 & 19.53 & 19.53 \\
\hline
\end{tabular}

Table 6: Minimum Inhibitory Concentrations of the leaf fractions.

\begin{tabular}{ccccc}
\hline $\begin{array}{c}\text { Leaf Fractions } \\
(\mu \mathrm{g} / \mathrm{mL})\end{array}$ & $\begin{array}{c}P . \\
\text { aeroginosa }\end{array}$ & S. aureus & E. coli & S. typhimurium \\
\hline Hexane & 312.5 & 156.25 & 78.125 & 156.25 \\
Butanol & 156.25 & 156.25 & 156.25 & 156.25 \\
Ethyl acetate & 78.125 & 156.25 & 78.125 & 78.125 \\
Water & 2500 & 1250 & 1250 & 625 \\
Gentamicin & 19.53 & 19.53 & 19.53 & 19.53 \\
\hline
\end{tabular}

Values are presented as mean SEM. $\mathrm{n}=3$. 


\section{The minimum inhibitory concentration (MIC) of the leaf fractions}

The minimum inhibitory concentration (MIC) of the fractions of the crude leaf methanol extract against some bacteria is shown on Table 6 . The water fraction of the leaf methanol extract had the worst MIC (highest MIC) on all the test bacteria. It's worst MIC $(2500 \mu \mathrm{g} / \mathrm{ml})$ was on P. aeruginosa while its best MIC (lowest MIC) of $625 \mu \mathrm{g} / \mathrm{mL}$ was on S. typhymurium. The hexane fraction was least active on $P$. aeruginosa with MIC of $312.5 \mu \mathrm{g} / \mathrm{mL}$ and most active on E. coli with MIC as low as $78.125 \mu \mathrm{g} / \mathrm{mL}$.

The hexane fraction had MIC of $156.25 \mu \mathrm{g} / \mathrm{mL}$ on all the remaining bacteria, as seen in Table 6. The butanol fraction had MIC of $156.25 \mu \mathrm{g} / \mathrm{mL}$ on all the test bacteria. The leaf ethyl acetate fraction showed the best antibacterial activity with MIC of $78.125 \mu \mathrm{g} / \mathrm{mL}$ against all the test bacteria with the exception of S. aureus in what case the MIC was 156.25 $\mu \mathrm{g} / \mathrm{mL}$ (Table 6).

\section{DISCUSSION}

This study was undertaken to obtain preliminary information on the phytochemical composition, proximate constituents and antimicrobial activity of crude methanolic extracts of different parts of D. mespiliformis and its fractions against four bacterial stains. Standard methods and the hole-in-plate bioassay procedure was used in this study. The extract yield of the leaves extract of D. mespiliformis $(28.2 \%)$ is higher than that produced by the bark $(6.7 \%)$ and root $(5.16 \%)$. This suggests that the harvest of the leaf for any purpose common to these plant parts will be more ecologically friendly as just little of the leaves should be harvested. Previous studies have attempted to evaluate the plant for its phytochemical constituents and antimicrobial activity. ${ }^{6,15}$ This is aimed at ascertaining its folkloric use in medicine. The plant, D. mespiliformis, has been traditionally used to treat diarrhea, pneumonia, fever, syphilis and wound..$^{8-13}$ It has earlier been reported that the ethanol leaves extract of $D$. mespiliformis contains tannins, volatile oils, carbohydrates, anthraquinones, alkaloids and flavonoids ${ }^{27}$ which is in agreement with findings of this study. Additionally, in this study, saponins were detected in the extracts of D. mespiliformis which is in contrast to earlier report where the ethanol extract of the root of $D$. mespiliformis was shown not to contain saponins. ${ }^{20}$ The variations in the presence of some secondary metabolites contained in the different parts of the plant could be due to differences in extraction methods and solvents used, as these factors influences phytochemistry both qualitatively and quantitatively. ${ }^{28}$ The roots and bark acetyl acetate fractions of $D$. mespiliformis were observed from the result to demonstrate broad antimicrobial activity in a dose dependent manner. Similar observation involving the ethanolic and methanolic extract of the plant have earlier been reported by. ${ }^{6,15}$ Gentamicin $(6,12,18$ and $24 \mathrm{mg} / \mathrm{mL})$, used as the positive control in the experiment provides the comparison of the activity of the extracts and gentamicin [Table 3]. The result shows all the fractions were able to inhibit the growths of Staphylococcus aureus, Salmonella typhymurium, Pseudomonas aeruginosa and Escherichia coli at concentrations that are as low as $6 \mathrm{mg} / \mathrm{mL}$. Thus indicative of the potency of the plant parts fractions. In addition, the leaf and bark ethyl acetate fractions at the tested concentrations reveal activities that are comparable to that of gentamicin on all of the organism.

The MIC of the crude methanolic extracts of the barks, leaves and roots of D. mespiliformis showed that the leaf methanol extract had the best antimicrobial effect. Similarly, the ethyl acetate fraction of the leaves had the highest antibacterial effect as shown by its low MIC against most of the tested pathogens, this may suggest that the active principles contained in the ethyl acetate fraction is of intermediate polarity since ethyl acetate mainly extracts compounds of intermediate polarity in plants. ${ }^{28}$
Phytochemical compounds are known to support bioactive activities in medicinal plants and are thus responsible for the antibacterial activities of this plant. Tannins are known to be useful in treatment of inflamed tissue and in the prevention of cancer. ${ }^{29}$ Similarly, drugs containing tannin have been reported to precipitate protein thereby inhibiting cell protein synthesis, thus associated with antibacterial activity. ${ }^{30}$ In the present study, the presence of tannin and flavonoids in the D. mespiliformis extract could possibly be responsible for the powerful antibacterial activity exhibited by the plant. This findings is consistent with earlier studies. ${ }^{27,31}$ The quantification of mineral composition provides a valid nutritive potential indulged in D. mespiliformis. Findings from this study conform that the source opted for the present investigation holds positive and can be recommended as an effective antibacterial agent against harmful bacterial strains in the future.

\section{CONCLUSION}

The crude methanol extracts of the leaf and root of the plant possessed bioactive constituents and demonstrated broad spectrum antimicrobial activity in a dose dependent manner in relative to other extracts of the plant.

\section{ACKNOWLEDGEMENT}

This study was supported by the Staff Training and Development Office (STDO), Usmanu Danfodiyo University, Sokoto, Nigeria.

\section{CONFLICT OF INTEREST}

The authors declare no conflict of interest.

\section{ABBREVIATIONS}

ANOVA: Analysis of variance; CFU: Colony Forming Unit; D. mespiliformis: Diospyros mespiliformis; E. coli: Escherichia coli; HEL: Hexane fraction of the leaf; INT: -(4-iodophenyl)-3-(4-nitrophenyl)-5-phenyl2H-tetrazolium chloride; LEF: Leaf ethyl acetate fraction; LD $_{50}:$ Median lethal dose; MIC: Minimum inhibitory concentration; MH: Mueller Hinton; MRSA: Methicillin-resistant Staphylococcus aureus; P. aeruginosa: Pseudomonas aeruginosa; S. typhumurium: Salmonella typhymurium; S. aureus: Staphylococcus aureus; SEM: Standard error of mean; WHO: World health organization.

\section{REFERENCES}

1. Bisi-Johnson MA, Obi CL, Eloff JN, Samuel BB, Baba K, Vasaiar S, et al Can Herbal Remedies be the Answer to Multidrug Resistance? Profile of Drug Resistance in Salmonella Species in Eatern Cape, South Africa. Journal of Experimental and Integrative Medicine. 2012;2(2):147-53.

2. Cooper RA, Jenkins L, Hooper S. Inhibition of Pseudomonas aeruginosa Biofilins by Medihoney. Journal of Wound Care. 2014;23(3):93-104.

3. Ananda AD. Wound Case with Traditional Complementary and Alternative Medicine. Indian Journal of Plastic Surgery. 2012:45(2):418-24.

4. Newman DJ, Cragg GM. Natural Products as Sources of New Drugs over the Last 25 Years. Journal of Natural Products. 2007;70(3):461-77.

5. Street RA, Prinsloo G. Commercially Important Medicinal Plants in South Africa: A Review. Journal of Chemistry. 2013;16. Article ID 205048.

6. Dangogo SM, Hassan LG, Sadiq LS, Manga SB. Phytochemical Analysis and Antibacterial Screening of Leaves of Diospyros mespilifornis and Ziziphus spinachristi. Journal of Chemical Engineering. 2012;1(1):13-7.

7. Ekop AS. Determination of chemical composition of Gnetum Africana (AFANG seeds. Pakistan Journal of Nutrition. 2007:6(1):40-3.

8. Irvine FR. Woody plants of Ghana. Oxford University Press, London. 1961

9. Gyang SN. Phytochemical screenings of the root bark of Diospyros mespiliformis Hoechst ex.A.Dc. Dissertation, University of Jos. 2001.

10. Mohamed IE, ELNur EB, Choudhary MI, Khan SN. Bioactive natural products from two Sudanese Medicinal plants Diospyros mespiliformis and Croton zambesic us. Natural Product Research. 2009;3(4):198.

11. Watt JM, Brandwiik MG. The Medicinal and Poisonous Plants of Southern and Eastern Africa. 2nd Edition Livingstone Edinburg. 1962;369 
12. Adzu B, Amos S, Dzarma S, Muazzam I, Gammaniel KS. Pharmacological evidence favouring the folkloric use of Diospyros mespiliformis Hochst in the relief of pain and fever. Journal of Ethnopharmacology. 2002;3(82):191-5.

13. Abubakar MS, Musa AM, Ahmed A, Hussaini IM. The Perception and Practice of Traditional Medicine in the Treatment of Cancers and Inflammations by Hausa and Fulani tribes of Northern Nigeria. Journal of Ethnopharmacology. 2007; 111 (3):625-9

14. Adzu B, Salawu OA. Screening Diospyros mespiliformis extract for antimalarial potency. International Journal of Biological and Chemical Sciences. 2009;3(2):1232-44

15. Oluremi BB, Osungunna MO, Ogbole OO. Phytochemical and Antimicrobial Screening of the Leaf Extract of Diospyros barteri. Gurke. Pharmacognosy Journal. 2010;2(11):405-8.

16. Javid A, Munir R. Bioassay Guided Fractionation of Withania somnifera for the Management Ascochyta Rabiei. International Journal of Agricultural Biology. 2012;14(15):797.

17. Harbone JB. Phytochemical Screening Methods: A Guide to Modern Techniques in Plant Analysis. Chapman and Hall. 1984;10(1):100-17.

18. Sofowora A. Medicinal Plants and Traditional Medicine in Africa. Spectrum Books Ltd. 1998;17.

19. EL-Olemyl MM, AL-Muhtadi FJ, Afifi AA. Experimental Phytochemistry. A Laboratory Manual College of Pharmacy, King Saud University. King Saud University Press. 1994;1-134

20. Trease GE, Evans WC. Pharmacognosy. 13 $3^{\text {th }}$ Ed. ELBS/Bailliere Tindal, London. 345-6 (Carbohydrate), 535-6 (Cyanogen Etic Glycoside). 1989;772-3.

21. Association of Official Analytical Chemist. Official Method of Analysis International. $15^{\text {th }}$ edition. Washington: USA. 1999;127-36.
22. Association of Official Analytical Chemist. Official Method of Analysis International. $17^{\text {th }}$ edition. Washington: USA. 2000;17-8.

23. Vlietink AJ, Vanhoof L, Tottle J, Lasure A, Vandeh D, Rwangabo PC, et al. Screening of One Hundred Rwandese Medicinal Plants for Antimicrobial and Antiviral Properties. Journal of Ethnopharmacology. 1995;46(1):431-71.

24. Eloff JN. A Sensitive and Quick Microplate Method to Determine the Minimal Inhibitory Concentration of Plant Extracts for Bacteria. Planta Medica. 1998a;64(8):711-3

25. Eloff JN. Which Extractant Should be used for Screening and Isolation of Antimicrobial Components of Plant. Journal of Ethnopharmacology. 1998b;60(1):1-8.

26. Ishaku LE, Jean-Paul D, Francien SB, Eloff JN. The Efficacy and Safety of Nine South African Medicinal Plants in Controlling Bacillus Anthracis Sterne Vaccine Strain. Biomed Central. 2016;0980(1):6-15

27. Shagal $\mathrm{MH}$, Kubmarawa $\mathrm{D}$, Alim H. Pliminary Phytochemical Investigation and Antimicrobial Evaluation of Root, Stem-Bark and Leaf Extracts of Diospyros mespliformis. International Research Journal of Biochemistry. 2012;2(1):11-5.

28. Edeoga HO, Okwu DE, Mbaebie BO. Phytochemical Constituents of some Nigerian Medicinal Plants. African Journal of Biotechnology. 2005;4(7):685-8.

29. Ruch RJ, Cheng SJ, Klaunig JE. Prevention of cytotoxicity and inhibition of Intercellular communication by antioxidant catechins isolated from Chinese green tea. Carcinogens. 1989;10(6):1003-8.

30. Shimada T. Salivary proteins as a defense against dietary tannins. Journal of Chemical Ecology. 2006;32(6):1149-63.

31. Chrinius H, Gary GY, Gideon AS, Asabe MM, Abel SA. Phytochemical and antimicrobial screening of methanol and aqueous extracts of agave sisalana. Acta Poloniae Pharmaceutica ñ Drug Research. 2011;68(4):535-9.

\section{GRAPHICAL ABSTRACT}

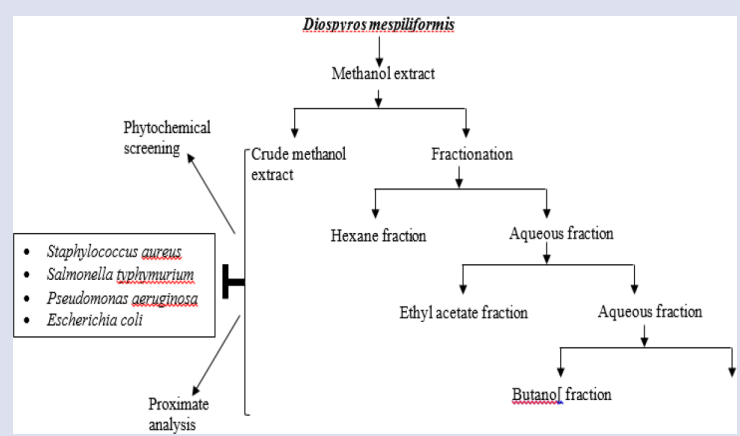

\section{SUMMARY}

- A wide range of antibiotics are being used at present to treat certain infections. However, adverse effects like hypersensitivity (e.g penicillin), ototoxicity (e.g. aminoglycosides) have been reported following their use. Apart from these discouraging side effects of many antibiotics, pathogens have also been shown to develop resistance to the antibiotics targeted against them. In this this present study, D. mespiliformis was investigated for its phytochemical composition, proximate constituent as well as its antimicrobial potential. Findings from the study, revealed that the crude methanolic extract of $D$. mespiliformis and its fractions possessed bioactive constituents and demonstrated broad spectrum antimicrobial activity in a dose dependent manner.

\section{ABOUT AUTHORS}

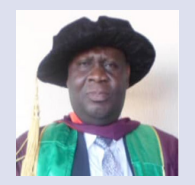

Abdullahi Aliyu Ebbo has completed his primary education in 1981 at Ebbo primary school and obtained his secondary school leaving certificate in 1987. Then he joined Usmanu Danfodiyo University Sokoto in 1988 and obtained a Doctor of Veterinary Medicine (DVM) Degree in 1996. Upon completion he had his mandatory one year National Youth Service Corps (NYSC) at State veterinary clinic Port Harcourt in the year 1997/89 before joining the University in 2002 as an Assistant lecturer. Then he obtained his MSc and PhD degrees in Veterinary Pharmacology from UDUS and Ahmadu Bello University, Zaria in the year 2006 and 2016 respectively. His research focuses on Ethnopharmacology and Pharmacognosy. He is currently workinkg as a Senior Lecturer in the Department of Veterinary Pharmacology and Toxicology, Faculty of Veterinary Medicine.

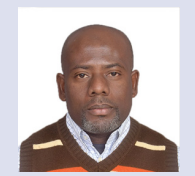

Dahiru Sani has completed his primary school in 1988 then he obtained the secondary school leaving certificate in 1993. He bagged Doctorate of Veterinary Medicine (DVM) degree in 2002. Upon completion, he had his compulsory one year National Youth Service Corps (NYSC) at Veterinary clinic, Alkaleri, Bauchi State before joining the service of Sokoto State Government as a Veterinary Officer in 2004. Then he obtained his MSc and PhD degrees in Pharmacology and Toxicology from University of Maiduguri and University Putra Malaysia in the years 2010 and 2016 respectively. His research focuses on Medicinal Plants, Neuropharmacology, Toxicology, Behavioral Studies, Molecular Targets and Cancer Research. He is currently working with Ahmadu Bello University as a Senior Lecturer in the Faculty of Veterinary Medicine, Department of Veterinary Pharmacology and Toxicology.

Dr Abubakar Ahmed attended Ahmadu Bello University Zaria, Nigeria where he obtained Bachelor Degree in Chemistry, MSc. Pharmacognosy and PhD Pharmacognosy. He is currently working with the same University. 


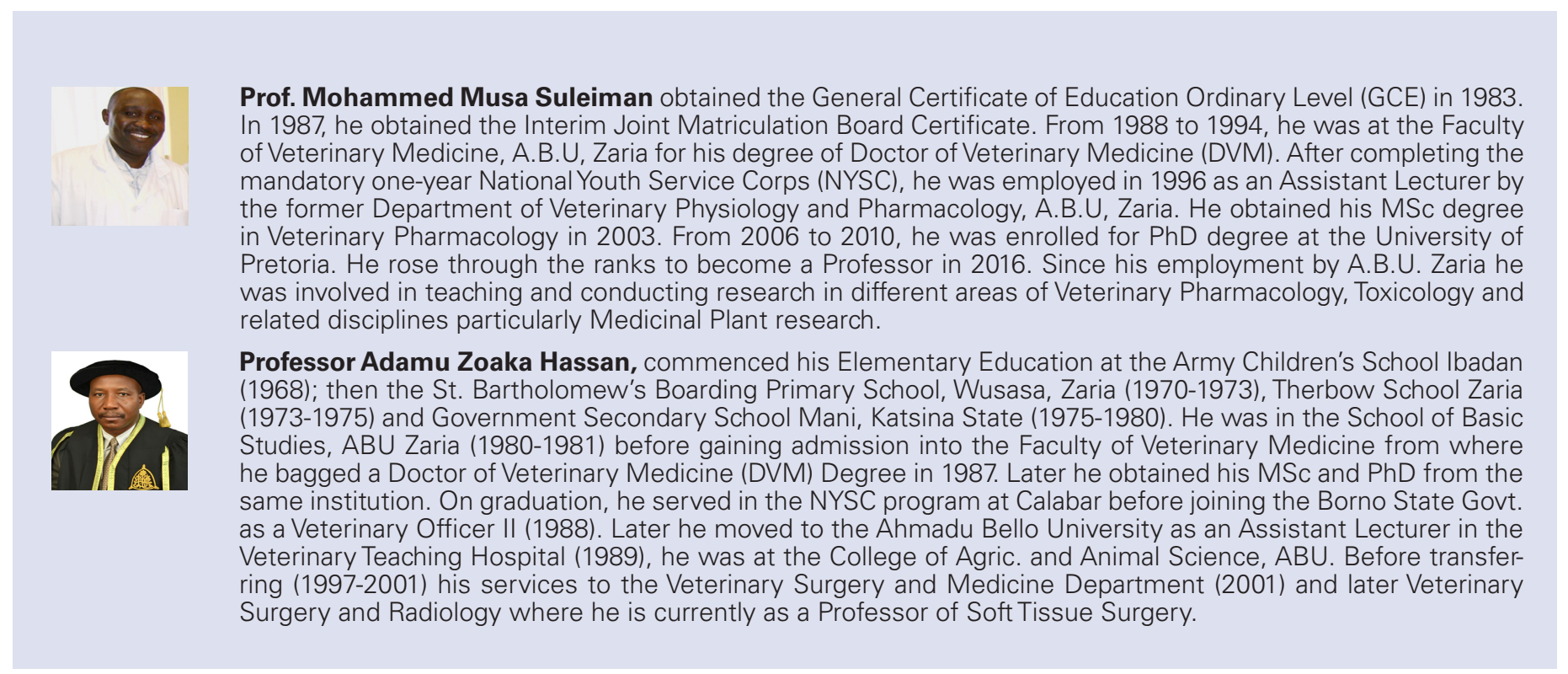

Cite this article: Ebbo AA, Sani D, Suleiman MM, Ahmed A, Hassan AZ. Phytochemical Composition, Proximate Analysis and Antimicrobial Screening of the Methanolic Extract of Diospyros mespiliformis Hochst ex a. Dc (Ebenaceae). Pharmacog J. 2019;11(2):362-8. 